\title{
TRATAMENTO TÉRMICO DO LEITE ACONDICIONADO EM FILME PLÁSTICO EM BANHO-MARIA
}

\author{
A.J.de Oliveira; C.R. Gallo; C.M.de CaRValho \\ Departamento de Ciencia e Tecnologia Agroindustrial - ESALOJUSP - C.P. 9 - CEP: 13418-900 - Piracicaba,SP.
}

\begin{abstract}
RESUMO: O presente trabalho foi realizado com a finalidade de se conseguir um procedimento de pasteurização prático e de baixo custo para pequenos produtores de leite, assegurando assim un aumento do tempo de conservação e consequentemente de comercializaçāo do produto, sem riscos para o consumidor. Para tal, amostras de leite já acondicionadas em filme plástico (1 litro) foram submetidas a diferentes tratamentos térmicos, sempre utilizando-se banho-maria a $70 \pm 1,0^{\circ} \mathrm{C}$ e variando-se os tempos de exposiçåo. Os resultados obtidos se mostraram satisfatórios sob o ponto de vista físico-químico e microbiológico, redurindo drasticamente em pouco tempo de exposição a população microbiana e eliminando totalmente as bactérias coliformes totais e fecais presentes no leite cru.

Decritores: leite, bactéria, coliformes, tratamento térmico
\end{abstract}

\section{HEAT TREATMENT OF RAW MILK IN PLASTIC BAGS}

ABSTRACT: In this study one litre plastic bags, filled with raw milk were submited to heat treatments in water bath at $70 \pm 1,0^{\circ} \mathrm{C}$. The time of treatment raried from 5 to 25 minutes. The results found showed that the heat treatments did not affect the physical-chemical properties of milk at any time and reduced the total microbial population at levels compatible with the Bravilian legal standards and eliminated completely total and feacal coliforms present in the raw milk.

Key Woris: milk, bacteria, coliforms, heat treatment

\section{INTRODUÇÃO}

O leite é um alimento natural, reconhecido pelo excelente valor nutritivo, sendo considerado como o alimento que mais se aproxima dos padrões da perfeição. Ele tem feito parte da alimentação humana desde os primeiros tempos da civilização, sendo responsável pela saúde, vigor físico e mental de seus consumidores.

O leite é um alimento muito rico em matérias nutritivas, com elevado teor de água, $\mathrm{pH}$ próximo da neutralidade, razões que o tornam um produto altamente perecível, a menos que medidas tecnologicas sejam tomadas para aumentar sua vida útil.

O leite possui proteínas fundamentais à nutrição, exercendo função plástica de reparação celular, fornecendo tambem aminoácidos essenciais em quantidade adequada, favorecendo o crescimento e suplementando dietas alimentares.

A gordura do leite contribui com praticamente metade do valor calórico, além de veicular vitaminas lipossolúveis e fornecer ácidos graxos essenciais.
A lactose presente tem valor energético; no intestino, contribui para a melhor absorção de minerais e estimula o crescimento da microflora desejável, sintetizadora de ácidos orgânicos e

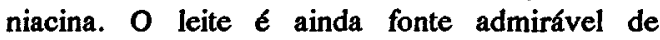
minerais necessários à nutrição humana, como o cálcio e o fósforo.

A produção higiênica do leite, tanto a nível de fazenda como a nível industrial, deve ser um fator indispensável, tanto do ponto de vista de saúde pública, como na obtenção de seus derivados. Mas, por melhor que seja esta obtenção do produto, microrganismos normalmente encontram-se como contaminantes do leite. Alguns deles são totalmente inofensivos à saúde, porém existem outros capazes de causar vários tipos de doenças. Assim sendo, a aplicação de tratamentos térmicos ao leite, como por exemplo a pasteurização que visa eliminar todos os microrganismos patogênicos eventualmente presentes é extremamente importante no sentido de assegurar ao consumidor um produto de alta qualidade sanitária, além de propiciar um aumento da vida útil do leite pela eliminação da maioria dos microrganismos presentes. 
A pasteurização do leite é dita baixa ou lenta quando o mesmo é aquecido a $65^{\circ} \mathrm{C}$ por 30 minutos e alta ou rápida quando feita a $72-75^{\circ} \mathrm{C}$ por 15-20 segundos. Após este tratamento térmico,

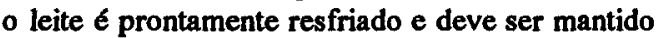
sob refrigeração $\left(<5,0^{\circ} \mathrm{C}\right)$.

Como normalmente os pequenos produtores de leite não dispõem de condições para - processamento térmico do leite produzido, os mesmos são obrigados a comercializarem o produto cru, rapidamente e a preços mais reduzidos.

Além disso, trata-se de uma matériaprima que dificilmente se mantêm em condições adequadas para utilização na fabricação de seus derivados.

Assim, o desenvolvimento de um processo de pasteurização simples e de baixo custo viria propiciar aos pequenos produtores a possibilidade de assegurarem um maior tempo de conservação do leite, bem como colocar no mercado um produto em melhores condições, tanto para consumo diretamente como para utilização do mesmo na produção de derivados.

\section{OBJETIVOS}

No presente trabalho objetivou-se: avaliar a eficiência de tratamento térmico em leite acondicionado em filme plástico, por vários períodos de tempo a $70 \pm 1,0^{\circ} \mathrm{C}$ em banho-maria, através de acompanhamento com contagens microbianas totais em placas, deteç̧ão da presença ou não de coliformes totais e fecais, $\mathrm{pH}$ e acidez.

Todas essas determinações foram realizadas no produto cru, após o tratamento térmico e após 3 e 7 dias de armazenamento sob refrigeração a $7 \pm 1,0^{\circ} \mathrm{C}$ do produto submetido à pasteurização.

\section{METODOLOGIA}

Amostras de leite cru envasadas em filmes plásticos pela Escola Superior de Agricultura "Luiz de Queiroz" de Piracicaba, foram conduzidas logo após a produção e analisadas para: contagem microbiana total em placas, presença ou não de coliformes totais e fecais, pH e acidez (\% ácido lático p/v), de acordo com BRASIL (1981); NASCIMENTO (1991); PEGNOLATTO (1976); REVILLA (1982) e RICHARDSON (1985).

Foram realizados 3 tratamentos térmicos no produto, como pode ser visto a seguir:
Tratamento Térmico 1: Três embalagens de um litro foram retiradas do refrigerador a $7 \pm 1,0^{\circ} \mathrm{C}$. Uma delas foi aberta assepticamente para retirada de amostras para as determinações químicas e microbiológicas do leite cru. A seguir foi colocada juntamente com as outras duas em banho-maria a $70 \pm 1,0^{\circ} \mathrm{C}$ por 5 minutos para estabilização da temperatura. A partir daí contaram-se os primeiros 5 minutos para a primeira amostragem e assim sucessivamente $(10,15,20$ e 25 minutos).

Não se verificou a temperatura no interior do leite a não ser aos 25 minutos (última amostragem), quando a temperatura no interior da embalagem aberta estava em $70^{\circ} \mathrm{C}$. As outras duas embalagens fechadas e mantidas por 25 minutos no banho foram resfriadas em água gelada colocadas em refrigerador a $7 \pm 1,0^{\circ} \mathrm{C}$, sendo uma delas aberta após 3 dias e a outra após 7 dias para as determinações químicas e microbiológicas.

Tratamento Térmico 2: Quatro embalagens de um litro foram retiradas do refrigerador a $7 \pm 1,0^{\circ} \mathrm{C}$. Uma delas foi aberta assepticamente para retirada de amostras para as determinações químicas e microbiolbgicas do leite cru. A seguir foi colocada juntamente com as outras três em banho-maria a 70 $\pm 1,0^{\circ} \mathrm{C}$. Aqui, uma segunda embalagern aberta $\mathrm{e}$ com um termômetro mergulhado no interior do leite, serviu como controle para se aguardar o tempo necessário para que a temperatura no interior da embalagem atingisse os $70^{\circ} \mathrm{C}$ e se estabilizasse. Este tempo foi de 7 minutos e a partir daí contaram-se os primeiros 5 minutos para a primeira amostragem e assim sucessivamente (1015-20 e 25 minutos). As outras duas embalagens fechadas e mantidas por 25 minutos a $70 \pm 1,0^{\circ} \mathrm{C}$, foram da mesma forma que no ensaio anterior, mantidas sob refrigeração a $7 \pm 1,0^{\circ} \mathrm{C}$ e abertas, uma após 3 dias e outra após 7 dias, para as mesmas determinações químicas e microbiológicas.

Tratamento Térmico 3: Quanto a um terceiro procedimento de aquecimento do leite foi realizado com a finalidade de determinar qual seria o efeito de 5 minutos de estabilização da temperatura $\left(67^{\circ} \mathrm{C}\right)$, sobre a flora microbiana do leite. Para tal, da mesma forma que nos experimentos 1 e 2 , três embalagens de um litro foram submetidas ao aquecimento em banho-maria a $70 \pm 1,0^{\circ} \mathrm{C}$ por 5 minutos. Decorridos 5 minutos, uma das embalagens foi aberta assepticamente para retirada de amostras para as análises químicas e microbiológicas, sendo as demais resfriadas 
imediatamente em água gelada e depois levadas ao refrigerador. Após 3 e 7 dias sob refrigeração estas amostras foram submetidas às mesmas análises descritas anteriormente.

As contagens microbianas totais de mesófilos foram realizadas em meio de cultivo PCA (Plate Count Agar - DIFCO 0479) com incubação a $35^{\circ} \mathrm{C} / 48 \mathrm{~h}$. Para a deteç̧ão de coliformes totais utilizou-se tubos com caldo verde brilhante lactose bile 2\% (VBLB - DIFCO 0007), com alíquotas de 10,1 e $0,1 \mathrm{ml}$ de leite, com incubação a $37^{\circ} \mathrm{C} / 24$ - $48 \mathrm{~h}$ e para a confirmação de coliformes fecais a partir dos tubos CVBLB positivos utilizou-se caldo EC (DIFCO-0314) com incubação a $45,5^{\circ} \mathrm{C} \mathrm{em}$ banho-maria por 24 horas.

\section{RESULTADOS E DISCUSSÃo}

Os dados obtidos no presente trabalho encontram-se nas TABELAS 1 e 2 (Tratamento Térmico 1), TABELAS 3 e 4 (Tratamento Térmico 2) e TABELAS 5 e 6 (Tratamento Térmico 3).

Também os dados encontrados nas contagens microbianas totais podem ser visualizados nas Figuras 1 (Gráficos 1 e 2, para a metodologia 1) e 2 (Gráficos 1 e 2, para a metodologia 2).

Pelos dados nota-se que esse tipo de pasteurização do leite já acondicionado em filme plástico, através do simples uso de um banho-maria a $70 \pm 1,0^{\circ} \mathrm{C}$, apresenta bons resultados sob 0 ponto de vista microbiológico, ou seja, reduz em pouco tempo de exposição drasticamente a população microbiana e elimina totalmente as bactérias coliformes tanto totais como fecais presentes no leite cru.

Nota-se que com tempo de exposição de 15 minutos, em todos os ensaios se obtiveram reduções superiores a um ciclo logarítmico na população microbiana, o que significa uma redução bastante grande dos microrganismos, o que irá favorecer a conservação do produto.

Já com 5 minutos de tratamento térmico a $70 \pm 1,0^{\circ} \mathrm{C}$, em alguns ensaios o resultado foi satisfatório quanto a redução da população microbiana $\mathrm{e} \mathrm{em}$ outros a redução não foi tão significativa, devendo-se portanto, optar por tempos maiores de aquecimento. Porém, em relação a destruição das bactérias coliformes, notase que este tempo reduzido de 5 minutos a $70 \pm$ $1,0^{\circ} \mathrm{C}$ já é suficiente para eliminação das mesmas.

Nota-se ainda, pela observação dos Gráficos nas Figuras 1 e 2, que os valores $D 70^{\circ} \mathrm{C}$ variaram de um experimento para outro, o que mostra a variação quanto à resistência térmica, das espécies microbianas presentes no leite.

Com 20 minutos de aquecimento a $70 \pm$ $1,0^{\circ} \mathrm{C}$ já ocorreram em alguns ensaios reduções de dois ciclos logarítmicos na população microbiana e não sendo este um processo de alto custo, pode ser aconselhado como um procedimento eficiente na pasteurização do leite.

Há no entanto, que se ampliar estes ensaios e acompanhar com testes sensoriais para melhor avaliar e correlacionar a eficiência da destruição microbiana com as características organolépticas do produto.

Com a aplicação deste procedimento simples, rápido e de baixo custo, para pasteurização do leite, com o menor tempo de exposição utilizada, ou seja, 5 minutos a $70 \pm$ $1,0^{\circ} \mathrm{C}$, conseguiu-se sob $\circ$ ponto de vista bacteriológico um leite pasteurizado tipo $\mathrm{B}$, segundo os padrões da Portaria 01/87 do Ministério da Saúde, que estabelece os seguintes valores:

\begin{tabular}{c|l|c|c}
\hline & $\begin{array}{l}\text { Leite } \\
\text { Pasteurizado }\end{array}$ & Tipo B & Tipo C \\
\cline { 2 - 4 } & $\begin{array}{l}\text { Salmonela } \\
\text { (Ausência em) }\end{array}$ & $25 \mathrm{ml}$ & $25 \mathrm{ml}$ \\
\hline \multirow{2}{*}{ NMP } & Coliformes totais & $4 / \mathrm{ml}$ & $10 / \mathrm{ml}$ \\
\cline { 2 - 4 } & Coliformes fecais & $1 / \mathrm{ml}$ & $2 / \mathrm{ml}$ \\
\hline \multirow{2}{*}{$\begin{array}{c}\text { UFC/ } \\
\text { ml }\end{array}$} & $\begin{array}{l}\text { Contagem padrão } \\
\text { em placas }\end{array}$ & $8,0 \times 104$ & $3,0 \times 105$ \\
\hline
\end{tabular}

Assim, pequenos produtores de leite poderão, observadas as ressalvas já efetuadas quanto a necessidade de mais dados em relação às determinações microbiológicas, testes sensoriais e físico-químicos do produto, se valer de uma técnica simples e de baixo custo para aumentar o tempo de conservação e consequentemente de comercialização, sem risco para o consumidor.

Ainda, pelos dados apresentados na TABELA 7, nota-se que não ocorreram variações marcantes tanto na população microbiana como nos valores de $\mathrm{pH}$ e acidez, conseguidos no dia do tratamento térmico e após 3 e 7 dias de armazenamento sob refrigeração.

Estes resultados mostram que com esse procedimento de pasteurização, o leite se mantêm sob refrigeração, sem alterações microbiológicas por um período de até 7 dias. 
TABELA 1 - Avaliação do efeito do tratamento térmico $n^{0} 1$ do leite sobre a população microbiana, pH e acidez (experimento de 06/05/92).

\begin{tabular}{llccccc}
\hline \hline & $\begin{array}{l}\text { Contagem } \\
\text { microbiana } \\
\text { Total } \\
\text { (UFC/ml) }\end{array}$ & $\begin{array}{l}\text { \% Redução } \\
\text { em relação } \\
\text { ao leite cru }\end{array}$ & $\begin{array}{c}\text { Coliformes } \\
\text { totais }\end{array}$ & $\begin{array}{c}\text { Coliformes } \\
\text { fecais }\end{array}$ & pH & $\begin{array}{c}\text { Acidez (\% } \\
\text { Ácido Lático } \\
\text { P/V) }\end{array}$ \\
\hline Leite cru & $7,3 \times 10^{4}$ & & $\begin{array}{c}\text { Presença } \\
\text { em 0,1 ml }\end{array}$ & Ausência & 6,89 & 0,1544 \\
$\begin{array}{l}\text { Banho-maria } \\
70^{\circ} \mathrm{C} / 5^{\prime}\end{array}$ & $6,0 \times 10^{3}$ & $-91,80$ & Ausência & Ausência & 6,91 & 0,1540 \\
$\begin{array}{l}\text { Banho-maria } \\
70^{\circ} \mathrm{C} / 10^{\prime}\end{array}$ & $8,0 \times 10^{3}$ & $-89,00$ & Ausência & Ausência & 6,91 & 0,1540 \\
$\begin{array}{l}\text { Banho-maria } \\
70^{\circ} \mathrm{C} / 15^{\prime}\end{array}$ & $3,3 \times 10^{3}$ & $-95,50$ & Ausência & Ausência & 6,85 & 0,1540 \\
$\begin{array}{l}\text { Banho-maria } \\
70^{\circ} \mathrm{C} / \mathbf{2 0}^{\prime}\end{array}$ & $2,6 \times 10^{3}$ & $-96,40$ & Ausência & Ausência & 6,90 & 0,1540 \\
$\begin{array}{l}\text { Banho-maria } \\
70^{\circ} \mathrm{C} / 25^{\prime}\end{array}$ & $2,2 \times 10^{3}$ & $-97,00$ & Ausência & Ausência & 6,89 & 0,1540 \\
\hline \hline
\end{tabular}

TABELA 2 - Avaliação do efeito do tratamento térmico $\mathrm{n}^{0} 1$ do leite sobre a população microbiana, $\mathrm{pH}$ e acidez (experimento de 14/05/92).

\begin{tabular}{lllllll}
\hline \hline & $\begin{array}{l}\text { Contagem } \\
\text { microbiana } \\
\text { Total } \\
\text { (UFC/ml) }\end{array}$ & $\begin{array}{c}\text { \% Redução } \\
\text { em relação } \\
\text { ao leite cru }\end{array}$ & $\begin{array}{c}\text { Coliformes } \\
\text { totais }\end{array}$ & $\begin{array}{c}\text { Coliformes } \\
\text { fecais }\end{array}$ & pH & $\begin{array}{c}\text { Acidez (\% } \\
\text { Ácido Lático } \\
\text { P/V) }\end{array}$ \\
\hline Leite cru & $2,5 \times 10^{5}$ & & $\begin{array}{c}\text { Presença } \\
\text { em 0,1 ml }\end{array}$ & $\begin{array}{c}\text { Presença } \\
\text { em 0,1 ml }\end{array}$ & 6,77 & 0,1422 \\
$\begin{array}{l}\text { Banho-maria } \\
70^{\circ} \mathrm{C} / 5^{\prime}\end{array}$ & $8,7 \times 10^{4}$ & $-65,20$ & Ausência & Ausência & 6,76 & 0,1422 \\
$\begin{array}{l}\text { Banho-maria } \\
70^{\circ} \mathrm{C} / 10^{\prime}\end{array}$ & $8,4 \times 10^{4}$ & $-66,40$ & Ausência & Ausência & 6,76 & 0,1422 \\
$\begin{array}{l}\text { Banho-maria } \\
70^{\circ} \mathrm{C} / 15^{\prime}\end{array}$ & $9,3 \times 10^{3}$ & $-96,30$ & Ausência & Ausência & 6,76 & 0,1341 \\
$\begin{array}{l}\text { Banho-maria } \\
70^{\circ} \mathrm{C} / 20^{\prime}\end{array}$ & $1,7 \times 10^{3}$ & $-99,30$ & Ausência & Ausência & 6,75 & 0,1341 \\
$\begin{array}{l}\text { Banho-maria } \\
70^{\circ} \mathrm{C} / 25^{\prime}\end{array}$ & $5,7 \times 10^{2}$ & $-99,80$ & Ausência & Ausência & 6,76 & 0,1341 \\
\hline \hline
\end{tabular}



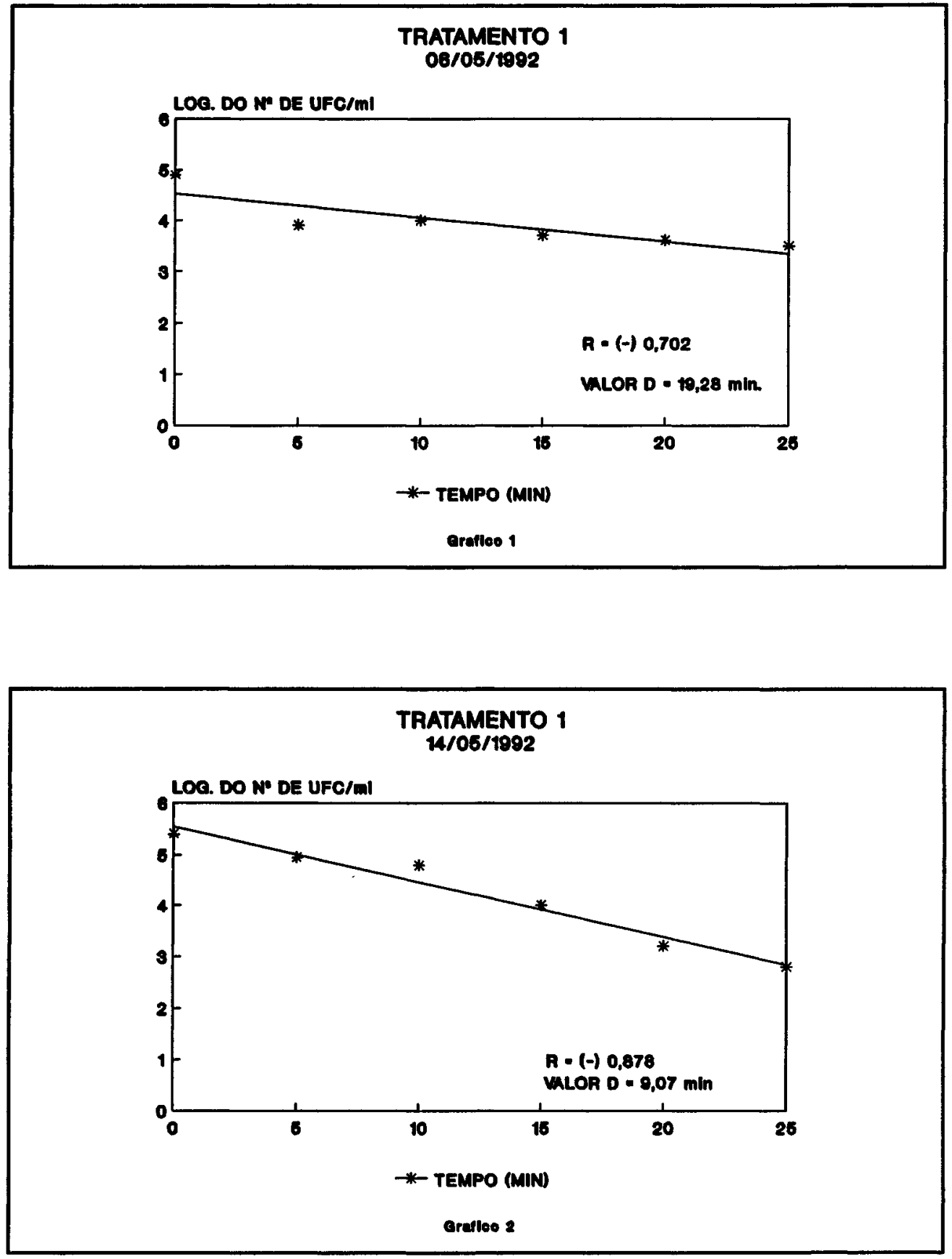

Figura 1. Efeito do tratamento térmico na redução da microbiota presente no leite.

Sci. agric., Piracicaba, 51(1):175-183,jan./abr., 1994 
TABELA 3 - Avaliação do efeito do tratamento térmico $n^{\circ} 2$ do leite sobre a população microbiana, pH e acidez (experimento de 21/05/92).

\begin{tabular}{|c|c|c|c|c|c|c|}
\hline & $\begin{array}{l}\text { Contagem } \\
\text { microbiana } \\
\text { Total } \\
\text { (UFC/ml) }\end{array}$ & $\begin{array}{l}\text { \% Redução } \\
\text { em relação } \\
\text { ao leite cru }\end{array}$ & $\begin{array}{c}\text { Coliformes } \\
\text { totais }\end{array}$ & $\begin{array}{l}\text { Coliformes } \\
\text { fecais }\end{array}$ & $\mathrm{pH}$ & $\begin{array}{c}\text { Acidez (\% } \\
\text { Ácido Lático } \\
\text { P/V) }\end{array}$ \\
\hline Leite cru & $2,8 \times 10^{5}$ & & $\begin{array}{l}\text { Presença } \\
\text { em } 0,1 \mathrm{ml}\end{array}$ & Ausência & 6,76 & 0,1341 \\
\hline $\begin{array}{l}\text { Banho-maria } \\
70^{\circ} \mathrm{C} / 5^{\prime}\end{array}$ & $2,6 \times 10^{5}$ & $-7,10$ & Ausência & Ausência & 6,68 & 0,1382 \\
\hline $\begin{array}{l}\text { Banho-maria } \\
70^{\circ} \mathrm{C} / 10^{\prime}\end{array}$ & $2,2 \times 10^{5}$ & $-21,40$ & Ausência & Ausência & 6,68 & 0,1382 \\
\hline $\begin{array}{l}\text { Banho-maria } \\
70^{\circ} \mathrm{C} / 15^{\prime}\end{array}$ & $1,5 \times 10^{4}$ & $-94,60$ & Ausência & Ausência & 6,68 & 0,1382 \\
\hline $\begin{array}{l}\text { Banho-maria } \\
70^{\circ} \mathrm{C} / 20^{\prime}\end{array}$ & $6,3 \times 10^{3}$ & $-97,80$ & Ausência & Ausência & 6,67 & 0,1341 \\
\hline $\begin{array}{l}\text { Banho-maria } \\
70^{\circ} \mathrm{C} / 25^{\prime}\end{array}$ & $7,9 \times 10^{3}$ & $-97,20$ & Ausência & Ausência & 6,67 & 0,1341 \\
\hline
\end{tabular}

TABELA 4 - Avaliação do efeito do tratamento térmico $n^{\circ} 2$ do leite sobre a população microbiana, pH e acidez (experimento de 28/05/92).

\begin{tabular}{lllcccc}
\hline \hline & $\begin{array}{l}\text { Contagem } \\
\text { microbiana } \\
\text { Total } \\
\text { (UFC/ml) }\end{array}$ & $\begin{array}{l}\text { \% Redução } \\
\text { em relação } \\
\text { ao leite cru }\end{array}$ & $\begin{array}{c}\text { Coliformes } \\
\text { totais }\end{array}$ & $\begin{array}{c}\text { Coliformes } \\
\text { fecais }\end{array}$ & pH & $\begin{array}{c}\text { Acidez (\% } \\
\text { Ácido Lático } \\
\text { P/V) }\end{array}$ \\
\hline Leite cru & $8,1 \times 10^{4}$ & & Presença \\
em 0,1 ml & Ausência & 6,63 & 0,13008 \\
$\begin{array}{l}\text { Banho-maria } \\
70^{\circ} \mathrm{C} / 5^{\prime}\end{array}$ & $1,9 \times 10^{4}$ & $-76,50$ & Ausência & Ausência & 6,58 & 0,1341 \\
$\begin{array}{l}\text { Banho-maria } \\
70^{\circ} \mathrm{C} / 10^{\prime}\end{array}$ & $1,4 \times 10^{4}$ & $-82,70$ & Ausência & Ausência & 6,56 & 0,13008 \\
$\begin{array}{l}\text { Banho-maria } \\
70^{\circ} \mathrm{C} / 15^{\prime}\end{array}$ & $1,6 \times 10^{3}$ & $-98,00$ & Ausência & Ausência & 6,56 & 0,1260 \\
$\begin{array}{l}\text { Banho-maria } \\
70^{\circ} \mathrm{C} / 20^{\prime}\end{array}$ & $7,1 \times 10^{2}$ & $-99,10$ & Ausência & Ausência & 6,56 & 0,1260 \\
$\begin{array}{l}\text { Banho-maria } \\
70^{\circ} \mathrm{C} / 25\end{array}$ & $4,5 \times 10^{2}$ & $-99,40$ & Ausência & Ausência & 6,56 & 0,1260 \\
\hline \hline
\end{tabular}


TRATAMENTO TÉRMICO DO LEITE ACONDICIONADO EM FILME PLÁSTICO EM BANHO-MARIA 181
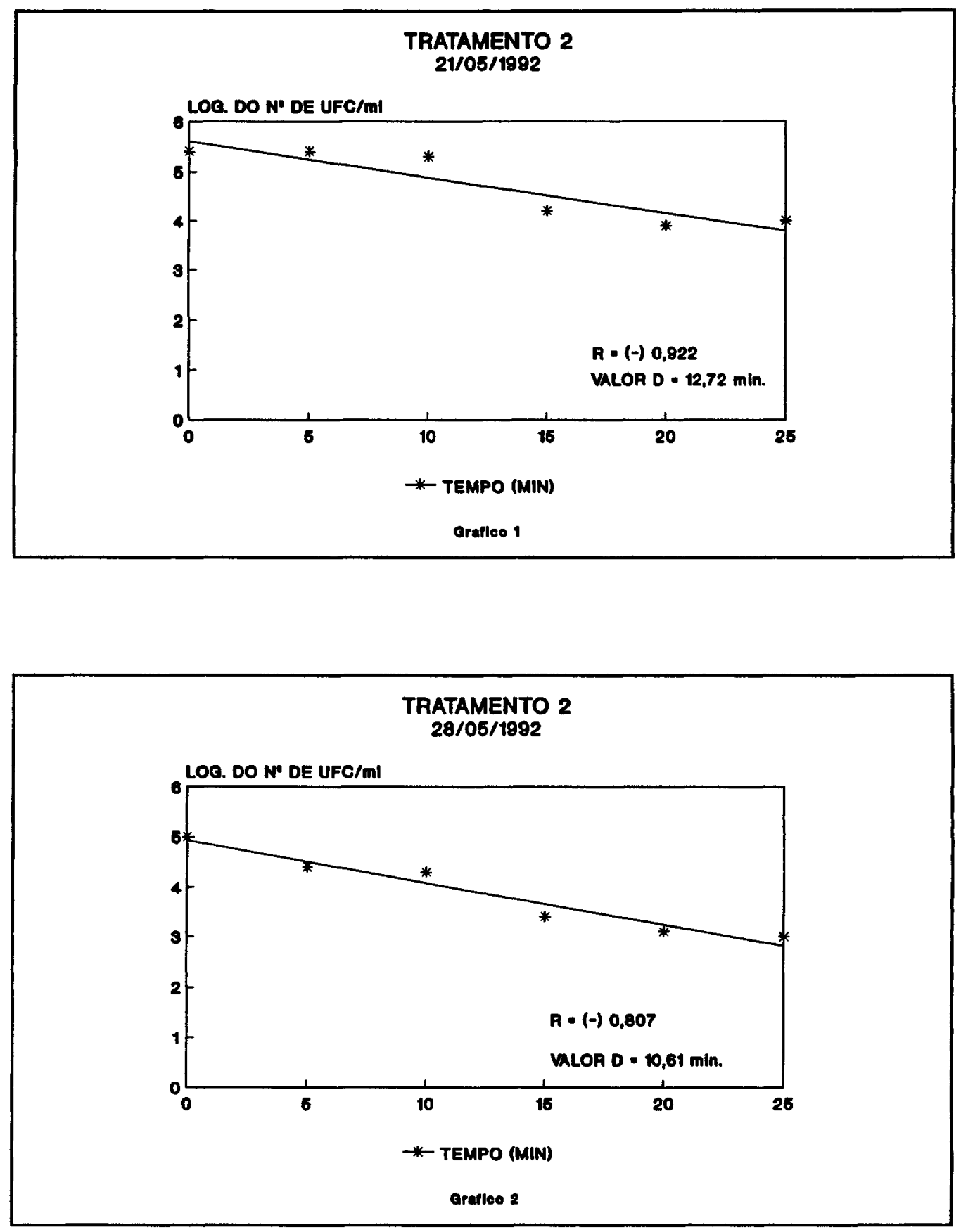

Figura 2. Efeito do tratamento térmico na redução da microbiota presente no leite.

Sci. agric., Piracicaba, 51(1):175-183, jan./abr., 1994 
TABELA 5 - Avaliação do tratamento térmico $n^{\circ} 3$ do leite sobre a população microbiana, pH e acidez (experimento sw 04/06/92.

\begin{tabular}{|c|c|c|c|c|c|c|}
\hline & $\begin{array}{l}\text { Contagem } \\
\text { microbiana } \\
\text { Total } \\
(\mathrm{UFC} / \mathrm{ml}) \\
\end{array}$ & $\begin{array}{l}\text { \% Redução } \\
\text { em relação } \\
\text { ao leite cru }\end{array}$ & $\begin{array}{l}\text { Coliformes } \\
\text { totais }\end{array}$ & $\begin{array}{l}\text { Coliformes } \\
\text { fecais }\end{array}$ & $\mathrm{pH}$ & $\begin{array}{l}\text { Acidez (\% } \\
\text { Ácido Lático } \\
\text { P/V) }\end{array}$ \\
\hline Leite cru & $1,9 \times 10^{5}$ & & $\begin{array}{l}\text { Presença } \\
\text { em } 0,1 \mathrm{ml}\end{array}$ & Ausência & 6,78 & 0,1420 \\
\hline $\begin{array}{l}\text { Banho-maria } \\
70^{\circ} \mathrm{C} / 5^{\prime}\end{array}$ & $6,5 \times 10^{4}$ & $-65,80$ & Ausência & Ausência & 6,80 & 0,1425 \\
\hline
\end{tabular}

TABELA 6 - Avaliação do tratamento térmico $n^{0} 3$ do leite sobre a população microbiana, pH e acidez (experimento de 11/06/92).

\begin{tabular}{llccccc}
\hline \hline & $\begin{array}{l}\text { Contagem } \\
\text { microbiana } \\
\text { Total } \\
\text { (UFC/ml) }\end{array}$ & $\begin{array}{c}\text { \% Redução } \\
\text { em relação } \\
\text { ao leite cru }\end{array}$ & $\begin{array}{c}\text { Coliformes } \\
\text { totais }\end{array}$ & $\begin{array}{c}\text { Coliformes } \\
\text { fecais }\end{array}$ & pH & $\begin{array}{c}\text { Acidez (\% } \\
\text { Ácido Lático } \\
\text { P/V) }\end{array}$ \\
\hline Leite cru & $2,2 \times 10^{5}$ & & $\begin{array}{c}\text { Presença } \\
\text { em } 0,1 \mathrm{ml} \\
\text { Ausência }\end{array}$ & Ausência & 6,75 & 0,1341 \\
$\begin{array}{l}\text { Banho-maria } \\
70^{\circ} \mathrm{C} / 5\end{array}$ & $8,0 \times 10^{4}$ & $-63,60$ & Ausência & 6,80 & 0,1345 \\
\hline \hline
\end{tabular}

TABELA 7 - Avaliação microbiológica, pH e acidez no dia do tratamento térmico e após 3 e 7 dias de armazenamento sob refrigeração

\begin{tabular}{|c|c|c|c|c|c|c|c|c|c|}
\hline \multirow[t]{2}{*}{$\begin{array}{l}\text { Tratamento } \\
\text { Térmico }\end{array}$} & \multicolumn{3}{|c|}{$\begin{array}{c}\text { Contagem Microbiana Total } \\
\mathrm{UFC} / \mathrm{ml}\end{array}$} & \multicolumn{3}{|c|}{$\mathrm{pH}$} & \multicolumn{3}{|c|}{$\begin{array}{c}\text { Acidez } \\
(\% \text { Ácido Lático p/v) } \\
\end{array}$} \\
\hline & $1^{\circ} \mathrm{dia}$ & $3^{\circ} \mathrm{dia}$ & $7^{\circ} \mathrm{dia}$ & $1^{\circ} \mathrm{dia}$ & $3^{\circ} \mathrm{dia}$ & $7^{\circ} \mathrm{dia}$ & $1^{\circ} \mathrm{dia}$ & $3^{\circ} \mathrm{dia}$ & $7^{\circ} \mathrm{dia}$ \\
\hline $\begin{array}{l}1^{\circ} \text { Experimento } \\
70^{\circ} \mathrm{C} / 25^{* *}\end{array}$ & $2,2 \times 10^{3}$ & $3,9 \times 10^{3}$ & $1,5 \times 10^{3}$ & 6,89 & 7,02 & 6,71 & 0,1540 & 0,1463 & 0,1422 \\
\hline $\begin{array}{l}2^{\circ} \text { Experimento } \\
70^{\circ} \mathrm{C} / 25^{* *}\end{array}$ & $5,7 \times 10^{2}$ & $4,2 \times 10^{2}$ & $6,1 \times 10^{\circ}$ & 6,76 & 6,79 & 6,82 & 0,1341 & 0,1301 & 0,1504 \\
\hline $\begin{array}{l}3^{\circ} \text { Experimento } \\
70^{\circ} \mathrm{C} / 25^{\prime *}\end{array}$ & $7,9 \times 10^{3}$ & $5,2 \times 10^{3}$ & $3,9 \times 10^{3}$ & 6,67 & 6,75 & 6,70 & 0,1341 & 0,1382 & 0,1341 \\
\hline $\begin{array}{l}4^{\circ} \text { Experimento } \\
70^{\circ} \mathrm{C} / 25^{\prime *}\end{array}$ & $4,5 \times 10^{2}$ & $3,2 \times 10^{2}$ & $1,4 \times 10^{\circ}$ & 6,56 & 6,70 & 6,68 & 0,1260 & 0,1382 & 0,1341 \\
\hline $\begin{array}{l}5^{\circ} \text { Experimento } \\
70^{\circ} \mathrm{C} / 5^{\prime * *}\end{array}$ & $6,5 \times 10^{4}$ & $5,7 \times 10^{4}$ & $5,2 \times 10^{4}$ & 6,80 & 6,84 & 6,90 & 0,1425 & 0,1460 & 0,1463 \\
\hline $\begin{array}{l}6^{\circ} \text { Experimento } \\
70^{\circ} \mathrm{C} / 5^{\text {mat }}\end{array}$ & $8,0 \times 10^{4}$ & $6,5 \times 10^{4}$ & $8,2 \times 10^{4}$ & 6,80 & 6,81 & 6,86 & 0,1345 & 0,1360 & 0,1400 \\
\hline
\end{tabular}

* = Tratamento Térmico 1; ** = Tratamento Térmico 2; *** = Tratamento Térmico 3 
Dados referentes às bactérias pertencentes ao grupo coliforme não foram colocados na TABELA 7, em função das mesmas não terem sido detectadas após qualquer dos tratamentos térmicos utilizados, ou seja, todos os tempos utilizados de 5 a 25 minutos a $70 \pm 1,0^{\circ} \mathrm{C}$ foram eficientes na destruição das bactérias coliformes (totais e fecais).

\section{CONCLUSÃo}

Embora o aquecimento do leite a $70 \pm$ $1,0^{\circ} \mathrm{C}$ por 20 minutos seja suficiente para provocar uma redução da carga microbiana correspondente a uma boa pasteurização, dada à grande variação da população microbiana do leite, tanto em número como espécie, para maior segurança recomenda-se o aquecimento a $70 \pm 1,0^{\circ} \mathrm{C}$ por 25 minutos.

\section{REFERÊNCIAS BIBLIOGRÁFICAS}

BRASIL. Ministério da Agricultura. Secretaria Nacional de Defesa Agropecuária. Laboratório Nacional de Referência Animal. Métodos analíticos oficiais para controle de produtos de origem animal e seus ingredientes. I. Métodos microbiológicos. Brasília, 1981. p.irreg.
NASCIMENTO, G.G.F. Condições microbiológicas do leite pasteurizado comercializado em Piracicaba,SP. Boletim da Sociedade Brasileira de Ciência e Tecnologia de Alimentos, Campinas, v.25, n.1, p.13-21, 1991.

PREGNOLATTO, W., (Coord.). Normas analíticas do Instituto Adolfo Lutz, 2.ed. São Paulo: Instituto Adolfo Lutz, 1976. v.1. 371p.

REVILLA, A. Tecnologia de la leche: procesamiento, manufactura y analisis. 2.ed. San José: IICA, 1982. 399 p.

RICHARDSON, G.H., ed. Standard methods for the examination of dairy products. 15.ed. Washington: American Public Health Association, 1985. 412p.

Enviado para publicação em 28.04.93 Aceito para publicação em 03.01.94 